\title{
13. Literary Ecologies and Post-9/11 Muslim Writing
}

Adnan Mahmutović

English, Stockholm University

This chapter seeks to outline some of the main topics and methodologies in the larger project that is a study of post-9/I I American Muslim writing in terms of Alexander Beecroft's literary ecologies. ${ }^{\mathrm{I}}$ Such an analysis requires an examination of the form and content of literary texts as well as their dissemination and reception, that is, the ways in which readers pull together authors and their works into $a$ literature within the field of world literature. If Beecroft is correct in claiming that $a$ literature is made mainly through the ways readers make connections between works - as well as authorial intentions in cases where writers aim at producing a particular type of literature it is possible to speak of American Muslim writing as a literature that belongs to different literary ecologies, for instance different national literatures. What is more, due to its reduced size, it is possible to speak of it as a form of vernacular literature (in a modified sense of the word I will explain later), but it is also possible to see it in terms of a cosmopolitan literature given its dissemination, translatability and accessibility. Since a large proportion of contemporary writers work in/towards what Beecroft calls the emerging global ecology, American Muslim writing may not only find itself pulled in

I Alexander Beecroft, An Ecology of World Literature: From Antiquity to the Present Day (London: Verso, 2015). See also the discussion of Beecroft in the general introduction to this volume.

How to cite this book chapter:

Mahmutović, Adnan. "Literary Ecologies and Post-9/I I Muslim Writing”. In World Literatures: Exploring the Cosmopolitan-Vernacular Exchange, edited by Stefan Helgesson, Annika Mörte Alling, Yvonne Lindqvist, and Helena Wulff, I 40-I 49. Stockholm: Stockholm University Press, 20I 8. DOI: https:// doi.org/IO.I6993/bat.m. License: CC-BY. 
several directions through the workings of literary markets and diverse audiences, but will also deliberately, through form and content, orient itself towards different ecologies. This is the main feature I see as defining American Muslim writing, namely its plural location and orientation. It is at the same time firmly located in American national literature but it constantly orients itself towards other national literatures and a global literary ecology.

The label "American Muslim" pulls together often very idiosyncratic works on the basis of interrelated sets of concerns as well as the fact that it is tied to and strongly defined by the American literary markets. To only locate certain writing in a national literary ecology and deem it a niche writing would, for American Muslim writing effectively stage a forgetting of the cosmopolitan heritage of Islam, which informs this writing and de facto produces its particular dynamic between location and orientation. Indeed, American Muslim writing is a product not only of our time but strongly informed by the continuous, fourteen-centuries-long form of what Alex MacGillivray calls "archaic globalization", which includes the history of Muslim colonialism and its economic and cultural impact on the world. What is more, we must not forget the notion of the Muslim Ummah as an early form of cosmopolitan consciousness, which I see strongly affects both the location and orientation of American Muslim writing. Indeed, by positing itself as a global project, Islam not only achieved a transcontinental reach centuries before European colonialism and industrialisation but continues to be an essential part of current globalisation processes and its effects are felt in world literatures, especially the types of literature produced by those for whom Muslim identity is at stake.

The practically non-existent use of the label "Muslim", in contrast to for instance national or ethnic tags, in more global marketing is not incidental. In the post-9/I I period, it may not provide social capital that can boost international success. At the same time, dealing with Muslim-related, often controversial subjects

2 Alex MacGillivray, A Brief History of Globalization (London: Robinson, 2006): I 5 . 
such as terrorism does boost sales and international distribution. ${ }^{3}$ In contrast to globally popular ways of disseminating categories and discussing literature, the tag "Muslim" does not appear much in critical reception (including reviews and interviews). A notable exception is for instance Rehana Ahmed's work. ${ }^{4}$

American Muslim writing, produced after I I September 200I in the USA, draws attention to complex orientations towards different literary ecologies. Here we find authors such as Mohsin Hamid, Michael Muhammad Knight, Khaled Hosseini, Mohja Kahf, Leila Lalami, Kamran Pasha, and a few others. These diverse works, often produced as some form of response to the post-9/I I historical developments, stage a particular dialectic between the cosmopolitan notions of flexible world citizen and location within national borders. ${ }^{5}$ American Muslim writing in this reading contains two movements elaborated in the critical dialogue between Richard Gray and Michael Rothberg: "centripetal” globalisation and a complementary centrifugal mapping that charts "the prosthetic reach of [the US] empire into other worlds". ${ }^{6}$ In contrast to the pervasive domestication of change in post-9/I I American literary ecology, which is not only visible in a lack of formal innovation but also in a failure to engage the global dimensions of that change, American Muslim writing does not exhibit Gray's "imaginative paralysis". ${ }^{7}$ What is more, the fact that this writing

3 Besides Mohsin Hamid's and Khaled Hosseini's work, we see this all over the world even with writers such as Tabish Khair's How to Fight Islamic Fundamentalism from the Missionary Position (Interlink Publishing Group, 2013) and Just Another Jihadi Jane (Interlink Publishing Group, 20I6). Works by for instance Leila Aboulela, which are more character-driven, subtle stories of identity crises, do not reach the required heghts of global literary markets to make any significant impact on the different ecologies.

4 Rehana Ahmed, Peter Morey, and Amina Yaqin, Culture, Diaspora and Modernity in Muslim Writing (New York and London: Routledge, 201 2).

5 Aihwa Ong, Flexible Citizenship: The Cultural Logic of Transnationality (London: Durham University Press, I999).

${ }^{6}$ Michael Rothberg, "A Failure of the Imagination: Diagnosing the Post9/I I Novel: A Response to Richard Gray", American Literary History 2I, no. I (2009): I 53 .

7 Richard Gray, "Open Doors, Closed Minds: American Prose Writing at a Time of Crisis”, American Literary History 2 I, no. I (2008): I 28-5 I. 
is read across multiple ethnoscapes, to use Arjun Appadurai's term, ${ }^{8}$ and that it often inspires change in different demographics, is an example of an ongoing oscillation between stable location and a strong need for global orientation.

I now want to show the use of Beecroft's ecological model as a way of highlighting the abovementioned, and crucial, features of American Muslim writing. Beecroft's model is useful because literature must "be understood as being in an ecological relationship to other phenomena - political, economic, sociocultural, religious - as well as to the other languages and literatures with which it is in contact". 9 An ecological lens helps us understand processes "of survival and recognition". ${ }^{\text {10 }}$ In his identification of basic types of ecologies - epichoric, panchoric, cosmopolitan, national, vernacular, global - Beecroft looks at the following factors: the linguistic situation, economy, the political world, religion, cultural politics and technologies of distribution. What we gain from seeing American Muslim writing in terms of literary ecologies is an expanded sense of diversity and crosspollination that explain certain defining features that pull together sets of works into a category which yields itself to analysis. While a more thorough investigation is needed to explore how all these factors shape $a$ literature, in this short overview, I will only touch upon some elements that are crucial for my analysis and do so by using specifics of Hamid and Muhammad Knight's work.

Linguistically speaking, though American Muslim writing is in English and thus affected by the literary history of this language, Beecroft is correct in claiming that one should look at "how many other languages exist as viable media for literary expression" and whether or not an author had a choice to write in that or another language. ${ }^{\text {II }}$ When it comes to American Muslim writing, while the authors do not seem to have had much of a choice (due to education, native-language proficiency etc.), there are several

\footnotetext{
8 Arjun Appadurai, Modernity at Large: Cultural Dimensions of Globalization (Minneapolis: University of Minnesota Press, I996).

9 Beecroft, An Ecology, I9.

1o Beecroft, An Ecology, 20.

II Beecroft, An Ecology, 25.
} 
other languages at play within the English language itself, as for instance Arabic, Urdu, Farsi, etc. because the authors have, either though ethnic or religious connections, access to and, in fact, a need to let these other languages seep into the prose itself. Arabic is particularly significant because it, according to Beecroft, "perhaps uniquely, remains extant as a literary cosmopolis today". ${ }^{\mathrm{I2}} \mathrm{In}$ other words, the cosmopolitan or global orientation of American Muslim writing is, language-wise, created not solely because English is a global lingua franca, but because of the previously mentioned cosmopolitan character of Islamic ideology and global spread. Arabic is de facto a default language of Islamic practice and the official language of Muslim Ummah, so that any prose that deals with it as an issue at stake will inevitably be coloured by its (at least) liturgic use.

Regarding the political world, it is indeed the nation that provides the strongest pull in American Muslim writing, but the fact of global politics with regard to the notion of Muslim-ness is omnipresent even if only implicitly. There is, in other words, at least an implicit demand for orientation towards global concerns. The same applies to the question of economy and the extent to which literature is "implicated ... in political, religious, and other symbolic networks". ${ }^{13}$ There is no doubt that American Muslim writing is commercialised exactly because it is, or can be, easily implicated in various symbolic networks. The Reluctant Fundamentalist is the case in point. ${ }^{14}$ Despite the importance of religion, we cannot, and should not, go into the degree of religious practice of the authors in questions, but there is no doubt that the religion of Islam, due to its continuous controversial political status, not only in the western hemisphere but also much of Asia, Africa and Australia, plays an enormous role in the way American Muslim writing is produced and received. Even in The Reluctant Fundamentalist, where religion is not even mentioned, it is implied to the extent that the narrative produces a sense of

\footnotetext{
I2 Beecroft, An Ecology, I43.

${ }_{3}$ Beecroft, An Ecology, 26.

${ }^{14}$ Mohsin Hamid, The Reluctant Fundamentalist (London: Penguin Books, 2007).
} 
unbearable absence of it, and in this way, it is nevertheless, perhaps even more strikingly, present.

When it comes to the cultural politics, the variety of Muslim writing shows that there is no one thing that defines them, but the presence of such politics is undeniable. ${ }^{15}$ Each of the mentioned authors is given certain cultural capital and used for different political purposes. Hamid is given the status of literary fiction, while Hosseini is easily slotted into the category of airport literature. The unique case of Muhammad Knight is necessarily sorted as underground literature, too raw to be sold as intellectually challenging. Kahf, in contrast, is a de facto Muslim-female voice, which shapes the reception in terms of a great deal of prejudiced expectations. The politics is closely tied to the technologies of distribution, because the print culture of our modern publishing seems to be hard to digest without perpetual creation and distribution of online content, E-books, audio books, TV and Radio interviews, readings and lectures recorded by audiences and posted on YouTube and social media. ${ }^{\mathrm{I}}$

Looking more closely at for instance Muhammad Knight's Taqwacores will show specifically how American Muslim writing is characterised by the dynamic between location and orientation both in terms of its content and the abovementioned ways of belonging to certain literary ecologies. It is the story of a house in Buffalo inhabited by Muslim youth from all major Islamic traditions, from Sunnis and Shias to mystics and even modern punk Muslims. The very fact of its identification as The Catcher in the Rye for young Muslims firmly situates it in the ecology of American national literature and the original way of distributing it, like it were some bootleg edition (DIY zine) or a pirated copy, indeed reinforces certain American cultural stereotypes of underground writing. It spread through niche venues, creating not only readers, but also followers, movements, and only much later, a film.

In many ways, it is an American story about young people trying to find their way (as Muslims) in America. There is music and

\footnotetext{
${ }^{15}$ Beecroft, An Ecology, 26.

i6 Beecroft, An Ecology, 27.
} 
drinking and cohabiting. The world outside is barely acknowledged. Besides the fact that they have visitors, the story is almost absolutely confined to the locality of their house. Despite the centrality and particularity of the house, the place appears transnational. It is not a home even though it evokes a desire for being located. It is a petri dish of variegated religious dogma and global youth culture. As such, this house in Buffalo, rather than a place in any country with Muslim majority, is a staggering metaphor for the diversity in the cosmopolitan house of Islam, the Ummah. Knight uses the typical metaphor of a microcosm containing the macrocosm to present intra-religious dynamics. The local is therefore ultimately global. This metaphoric character of the house effectively situates Islam in the US as part and parcel of the nation and, despite the sense of national claustrophobia, creates a centrifugal orientation towards the imagined global community of Ummah. But what keeps the youth together is the fact that they are American and not that they are Muslim. In fact, the impossibility of co-habitation of different kinds of Muslims in the house is suggestive of the impossibility of a homogenous Ummah, which remains an idea(l) of a cosmopolis.

If it were not for this orientation out, the novel would have a somewhat vernacular character. I am using vernacular here not simply to denote language but a certain way of shape-taking of a new type of literature. Given its peculiarity the novel reads like a niche work within the American literary ecology. It establishes an aesthetic which one can imagine as something that could become a form of a communal genre, or a genre for a particular streak in American-Muslim communities. Indeed, we have seen this in the very development of the Muslim punk scene as one of the many responses to the novel.

What also produces a dynamic between some form of vernacular (within nation) and cosmopolitan literary ecology, is the use of language, which makes the reader see beyond the national ecology. The English of Taqwacores is often skilfully broken up and stitched together with liturgic Arabic to the point of appearing as some form of global-vernacular that would more easily be spoken and understood by Muslims around the globe than general American readership. The opening sentence -“Bismillahir, Rahmanir and so 
on" ${ }^{17}$ - would, for a Muslim reader, speak volumes. This is, no doubt, rather basic code switching, but stylistically, unlike many other works written by Muslims or with Muslim characters, the Qur'anic phrase is used as if it were entirely natural in English, the way phrases like "once upon a time" or "in the beginning there was" are frequently used. A Muslim reader would know that the Bismillah-opening is obligatory for any type of honest and halal work, used naturally without thinking, shows the character and intent of the narrator (automatically reliable), that the narrator speaks to a community (note that the "foreign" words are not typically italicised). It is the second part - "and so on" that is in italics like it were foreign to the first phrase. This "and so on" also appears disrespectful because the narrator refuses to repeat the entire phrase, as Muslims always do, but this speaking-by-rote of the phrase is implied. It is the very relaxed, or natural, way of code-switching that makes the language appear at the same time both very local (to the house) and global, because it speaks to Muslims all over the world.

It is, in some way a cosmopolitan or global language which creates rich signification for Muslims regardless of their ethnicity, nationality, particularity of religious practice and dogma, etc. It is not some vernacular developed in isolation, but a language produced in the meeting of two cosmopolitan languages, English and Arabic. The fact that a global Muslim audience would be able to appreciate this work in terms of its use of language produces a rather unique situation within and across literary ecologies. While a vernacular would, according to Beecroft, prevent wider distribution of the work, the novel's outward orientation makes us revise this analysis. Disregarding its potentially controversial content and language, this novel would be highly accessible to a Muslim readership around the globe while at the same also quite obscure for most global audiences. In other words, it appears both local and global given a particular type audience, and yet, because of

${ }^{17}$ Michael Muhammad Knight, Taqwacores (New York: Soft Skull Press, 2004): 5 . 
that, very local when considering what usually makes literature that is read widely across different ethnoscapes etc.

In addition, regarding dissemination, it is not only the movement of the text itself that defines it, but ultimately the taqwacore effect: the creation of Muslim punk bands and other such alternative music scene among Muslim youth. In other words, the content of the novel, though fictional, inspired a great deal of transnational movement among Muslims. ${ }^{18}$ The increased demand led to distribution by the publishers Alternative Tentacles and then Autonomedia. Asra Nomani has credited the novel as the source of the idea for woman-led prayer, which took place on 18 March 2005 with Amina Wadud acting as imam. ${ }^{19}$

In this overview, I have tried to show how American Muslim writing, seen through the lens of Beecroft's model is inherently defined by a complex oscillation between location (nation) and orientation (cosmopolitanism, globe). As such, American Muslim writing shows both the utility of Beecroft's model for world literature today and opens a critical space for its possible revision.

\section{Bibliography}

Ahmed, Rehana, Peter Morey, and Amina Yaqin. Culture, Diaspora and Modernity in Muslim Writing. New York: Routledge, $20 \mathrm{I} 2$.

Appadurai, Arjun. Modernity at Large: Cultural Dimensions of Globalization. Minneapolis: University of Minnesota Press, I996.

Beecroft, Alexander. An Ecology of World Literature: From Antiquity to the Present Day. London: Verso, 2015.

Fiscella, Anthony T. "From Muslim Punks to Taqwacore: An Incomplete History of Punk Islam”. Contemporary Islam 6, no. 3 (20I2): 255-8I.

I8 Mark LeVine, Heavy Metal Islam: Rock, Resistance, and the Struggle for the Soul of Islam (New York: Broadway Books, 2008); Anthony T. Fiscella, "From Muslim Punks to Taqwacore: An Incomplete History of Punk Islam", Contemporary Islam 6, no. 3 (20I 2): 25 5-8I.

19 Michael Muhammad Knight, Blue-eyed Devil: A Road Odyssey Through Islamic America (New York: Autonomedia, 2006): 206. 
Gray, Richard. “Open Doors, Closed Minds: American Prose Writing at a Time of Crisis". American Literary History 2 I, no. I (2008): I $28-5$ I.

Hamid, Mohsin. The Reluctant Fundamentalist. London: Penguin Books, 2007.

Kahf, Mohja. The Girl in the Tangerine Scarf. New York: Carroll \& Graf Publishers. 2006.

Khair, Tabish. How to Fight Islamic Fundamentalism from the Missionary Position. Interlink Publishing Group, 20I3.

—. Just Another Jihadi Jane. Interlink Publishing Group, 20 I6.

Muhammad Knight, Michael. Blue-eyed Devil: A Road Odyssey Through Islamic America. New York: Autonomedia, 2006, 2006.

—. Taqwacores. New York: Soft Skull Press, 2004.

LeVine, Mark. Heavy Metal Islam: Rock, Resistance, and the Struggle for the Soul of Islam. New York: Broadway Books, 2008.

MacGillivray, Alex. A Brief History of Globalization. London: Robinson, 2006.

Ong, Aihwa. Flexible Citizenship: The Cultural Logic of Transnationality. London: Durham University Press, I999.

Rothberg, Michael. "A Failure of the Imagination: Diagnosing the Post-9/I I Novel: A Response to Richard Gray". American Literary History 2I, no. I (2009): I 52-58. 